\title{
Chronic Menthol Does Not Change Stoichiometry or Functional Plasma Membrane Levels of Mouse $\alpha 3 \beta 4$-Containing Nicotinic Acetylcholine Receptors
}

\author{
Selvan Bavan, Charlene H. Kim, Brandon J. Henderson, and Henry A. Lester \\ Division of Biology and Biological Engineering, California Institute of Technology, Pasadena, California (S.B., C.H.K., H.A.L.); \\ and Department of Biomedical Sciences, Joan C. Edwards School of Medicine at Marshall University, Huntington, West Virginia \\ (B.J.H.)
}

Received October 5, 2018; accepted January 12, 2019

\begin{abstract}
Heteromeric $\alpha 3 \beta 4$ nicotinic acetylcholine (ACh) receptors (nAChRs) are pentameric ligand-gated cation channels that include at least two $\alpha 3$ and two $\beta 4$ subunits. They have functions in peripheral tissue and peripheral and central nervous systems. We examined the effects of chronic treatment with menthol, a major flavor additive in tobacco cigarettes and electronic nicotine delivery systems, on mouse $\alpha 3 \beta 4 \mathrm{nAChRs}$ transiently transfected into neuroblastoma-2a cells. Chronic menthol treatment at $500 \mathrm{nM}$, near the estimated menthol concentration in the brain following cigarette smoking, altered neither the [ACh]response relationship nor $\mathrm{Zn}^{2+}$ sensitivity of ACh-evoked currents, suggesting that menthol does not change $\alpha 3 \beta 4 \mathrm{nAChR}$ subunit stoichiometry. Chronic menthol treatment failed to change the current density (peak current amplitude/cell capacitance) of $100 \mu \mathrm{M}$ ACh-evoked currents. Chronic menthol
\end{abstract}

treatment accelerated desensitization of 100 and $200 \mu \mathrm{M} \mathrm{ACh-}$ evoked currents. Chronic nicotine treatment $(250 \mu \mathrm{M})$ decreased ACh-induced currents, and we found no additional effect of including chronic menthol. These data contrast with previously reported, marked effects of chronic menthol on $\beta 2^{*}$ $\mathrm{nAChRs}$ studied in the same expression system. Mechanistically, the data support the emerging interpretation that both chronic menthol and chronic nicotine act on nAChRs in the early exocytotic pathway, and that this pathway does not present a rate-limiting step to the export of $\alpha 3 \beta 4$ nAChRs; these $n A C h R s$ include endoplasmic reticulum (ER) export motifs but not ER retention motifs. Previous reports show that smoking mentholated cigarettes enhances tobacco addiction; but our results show that this effect is unlikely to arise via menthol actions on $\alpha 3 \beta 4 \mathrm{nAChRs}$.

\section{Introduction}

Smoking is the leading cause of preventable death worldwide (https://www.cdc.gov/tobacco/data_statistics/fact_sheets/ fast_facts/?index/html), and is responsible for $\sim 6$ million deaths annually (https://apps.who.int/iris/bitstream/handle/ 10665/272694/9789241514170-eng.pdf?ua=1). Nicotine causes smoking addiction through binding to pentameric ligandgated nicotinic acetylcholine receptors (nAChRs). Chronic exposure to nanomolar or micromolar concentrations causes upregulation of nAChRs at the plasma membrane (PM). This upregulation occurs partially because nicotine enters the endoplasmic reticulum (ER), binds there to nascent $\alpha 4 \beta 2$ nAChRs, acts as a post-translational pharmacological chaperone for these nAChRs, and consequently increases ER exit of these $\mathrm{nAChRs}$ via post-translational pharmacological chaperoning (Srinivasan et al., 2012b; Henderson and Lester, 2015). Nicotine upregulates $\mathrm{nAChR} \alpha 4$ or $\beta 2$ protein levels without

This study was supported by the National Institutes of Health [Grants DA037743, DA046335, and DA036061].

https://doi.org/10.1124/mol.118.114769. changing their mRNA levels (Flores et al., 1992; Marks et al., 1992; Buisson and Bertrand, 2001; Srinivasan et al., 2011).

Compared with smokers of nonmentholated cigarettes, smokers of mentholated cigarettes have higher upregulation of $\alpha 4 \beta 2$-containing $\mathrm{nAChR}$ densities in the brain (Brody et al., 2013). There were reduced rates of smoking cessation among smokers of menthol-containing compared with nonmentholcontaining cigarettes at both 4-week and 6-month checkups (Gandhi et al., 2009).

There is a molecular explanation from mouse studies for the addictive properties of nanomolar-range menthol treatment (Henderson et al., 2016, 2017). Chronic treatment ( $\sim 24$ hours) with menthol alone upregulates $\alpha 4$ and $\alpha 6$ $\mathrm{nAChR}$ subunits selectively in midbrain dopaminergic neurons in the ventral tegmental area and substantia nigra pars compacta (Henderson et al., 2016), whereas nicotine alone upregulates nAChR $\alpha 4$ number in GABAergic neurons of the substantia nigra pars reticulata (Nashmi and Lester, 2007; Xiao et al., 2009). Furthermore, chronic menthol treatment alone shifted stoichiometry toward lower sensitivity $(\alpha 4)_{3}(\beta 2)_{2}$ and $\alpha 6 \beta 2$ (non- $\beta 3$ ) from higher sensitivity $(\alpha 4)_{2}(\beta 2)_{3}$ and $\alpha 6 \beta 2 \beta 3 \mathrm{nAChR}$ populations, respectively

ABBREVIATIONS: ACh, acetylcholine; ER, endoplasmic reticulum; GFP, green fluorescent protein; HSD, honestly significant difference; nAChR, nicotinic acetylcholine receptor; Neuro-2a, neuroblastoma-2a; PM, plasma membrane; $\mathrm{R}_{\mathrm{s}}$, series resistance; $\mathrm{V}_{\mathrm{m}}$, membrane potential; WT, wild type. 
(Henderson et al., 2016). While chronic menthol treatment alone prevented nicotine reward-related behavior (Henderson et al., 2016), combined chronic menthol and nicotine treatment further enhanced reward-related behavior caused by chronic nicotine alone (Henderson et al., 2017). Additionally, chronic menthol treatment enhances nicotine-induced upregulation of $\alpha 4^{*}$ and $\alpha 4 \alpha 6^{*}$ nAChRs (Henderson et al., 2017).

The human $\alpha 3$-, $\alpha 5$-, and $\beta 4$-nAChR subunit gene cluster located on chromosome locus $15 q 24-25.1$ is linked to the risk of nicotine dependence and smoking-associated diseases, as well as to lung cancer among smokers (Saccone et al., 2007; Bierut et al., 2008; Spitz et al., 2008; Chen et al., 2009; Tobacco and Genetics Consortium, 2010). In a metaanalysis of 16 studies, 130 single nucleotide polymorphisms in 15q24-25.1 are associated with the number of cigarettes smoked a day, with rs1051730 in CHRNA3 having the strongest association (Tobacco and Genetics Consortium, 2010). Furthermore, subunits from the $\alpha 3-, \alpha 5-$, and $\beta 4-$ $\mathrm{nAChR}$ subunit gene cluster are expressed in the medial habenula-interpeduncular tract (Dineley-Miller and Patrick, 1992; Marks et al., 1992; Sheffield et al., 2000; Whiteaker et al., 2000, 2002; Grady et al., 2009; Shih et al., 2014) and contribute to nicotine dependence by influencing nicotine aversion in the medial habenula-interpeduncular midbrain pathway (Fowler et al., 2011; Frahm et al., 2011). Compared with patients who do not have lung cancer, $\alpha 3$ and $\beta 4$ nAChR-encoding genes are overexpressed in small-cell lung carcinoma of lung cancer patients (Improgo et al., 2010). Agonist activation of $\alpha 3 \beta 4 \mathrm{nAChRs}$ can promote viability of these lung carcinoma cells, whereas antagonism or knockdown of $\alpha 3 \beta 4 \mathrm{nAChRs}$ reduces viability of these cells (Improgo et al., 2013).

Similar to the inhibitory effects at human $\alpha 4 \beta 2 \mathrm{nAChRs}$ (Hans et al., 2012), (-)-menthol, when coapplied with $30 \mu \mathrm{M}$ acetylcholine $(\mathrm{ACh})$, is a noncompetitive antagonist at human $\mathrm{nAChR} \alpha 3 \beta 4\left(\mathrm{IC}_{50}=100 \mu \mathrm{M}\right)$, while also causing faster desensitization of ACh-evoked currents (Ton et al., 2015). It is of interest to observe chronic ( $\sim 24$ hours) effects of a much lower, pharmacologically relevant concentration of menthol on $\alpha 3 \beta 4 \mathrm{nAChRs}$, because the estimated concentration of menthol in a smoker's brain is $0.5-2.5 \mu \mathrm{M}$ (Henderson et al., 2016, 2017).

We examined effects of chronic menthol (500 nM, 24-30 hours) treatment alone and in combination with chronic nicotine on the two potential stoichiometries, $(\alpha 3)_{2}(\beta 4)_{3}$ and $(\alpha 3)_{3}(\beta 4)_{2}$, and on functional PM levels of mouse $\alpha 3 \beta 4$ nAChRs. The efficiency of assembly and trafficking of $\mathrm{nAChR}$ varies depending on the receptor subtypes and the cell system in which they are expressed (Crespi et al., 2018a). These nAChRs were transiently transfected in mouse neuroblastoma-2a (Neuro-2a) cells to determine whether $\alpha 3 \beta 4 \mathrm{nAChRs}$ mediate the addictive effects of menthol in mentholated cigarettes.

\section{Materials and Methods}

Reagents. (-)-Menthol, ( \pm )-menthol, (+)-menthol, (-)-nicotine hydrogen tartrate, and acetylcholine chloride were obtained from Sigma-Aldrich (St. Louis, MO). Menthol dose selection has been discussed previously and is based on an analysis estimating the concentration of menthol in the brain following a long-term exposure paradigm, as well as on preliminary concentration-response studies (Henderson et al., 2016, 2017).

Neuro-2a Cell Culture and Transient Transfection. We used mouse Neuro-2a cells (American Type Culture Collection, Manassas, VA) for our experiments. Passage 3-20 Neuro-2a cells $(50,000)$ were plated onto sterilized 12-mm-diameter glass coverslips (Deckgläser, Sondheim, Germany), which were placed in 35-mm culture dishes, and cultured in a humidified incubator $\left(37^{\circ} \mathrm{C}\right.$; $95 \%$ air, $\left.5 \% \mathrm{CO}_{2}\right)$. Neuro-2a cells were incubated in full cell culture medium containing Eagle's minimum essential medium, 10\% FBS, $100 \mathrm{U} / \mathrm{ml}$ of penicillin, and $100 \mu \mathrm{g} / \mathrm{ml}$ of streptomycin.

For both $\mathrm{Zn}^{2+}$-inhibition experiments and [ACh]-response experiments (Figs. 1-3; Tables 1-3), 35-mm culture dishes containing preplated Neuro-2a cells were transfected with $125 \mathrm{ng}$ of each nAChR subunit cDNA [mouse $\alpha 3$-green fluorescent protein (GFP) and mouse wild-type (WT) $\beta 4$ ] in the pCDNA3.1 vector. These constructs were used in Shih et al. (2014) and contain a GFP tag within the M3-M4 loop of mouse $\alpha 3$ nAChR. Plasmids were mixed with $250 \mu \mathrm{l}$ of Opti-MEM (Thermo Fisher Scientific Inc., Chino, CA) and Lipofectamine 2000 (Thermo Fisher Scientific Inc.) was separately mixed with $250 \mu \mathrm{l}$ of Opti-MEM. After 5 minutes at $24^{\circ} \mathrm{C}$, DNA- and Lipofectamine 2000-containing Opti-MEM solutions were mixed together and incubated for 25 minutes at $24^{\circ} \mathrm{C}$. The solutions were then added to $35-\mathrm{mm}$ culture dishes containing preplated Neuro-2a cells, which were then placed in the humidified incubator for 24 hours. The Opti-MEM was removed and replaced with full cell culture media containing either $500 \mathrm{nM}(-)$-menthol, $500 \mathrm{nM}(+)$-menthol, $500 \mathrm{nM}( \pm)$-menthol, $250 \mu \mathrm{M}(-)$-nicotine, combined $500 \mathrm{nM}(-)$-menthol and $250 \mu \mathrm{M}(-)$-nicotine, or neither menthol nor nicotine (control treatment) for 24-30 hours. Filter $(0.2 \mu \mathrm{m})$-sterilized menthol and nicotine stock solutions were used to make $500 \mathrm{nM}$ menthol and/or $250 \mu \mathrm{M}$ nicotine.

Patch-Clamp Electrophysiology. Neuro-2a cells were visualized with an inverted microscope (IX71; Olympus, Tokyo, Japan) and green illumination (for visualizing fluorescent proteins). Whole-cell patch-clamp techniques were used with an Axopatch 200B amplifier (Molecular Devices Axon Instruments, Sunnyvale, CA), Digidata 1440A analog-to-digital converters (Molecular Devices Axon Instruments), and pClamp 10.3 software (Molecular Devices Axon Instruments). Data were sampled at $10 \mathrm{kHz}$ and low-pass Bessel filtered at $2 \mathrm{kHz}$. Patch electrodes had a resistance of $2-6 \mathrm{M} \Omega$ when filled with intracellular solution. Series resistance $\left(R_{s}\right)$ was compensated by $85 \%-95 \%$ throughout whole-cell patch-clamp recording, and data were discarded if the $R_{\mathrm{s}}$ exceeded $25 \mathrm{M} \Omega$ at the start or end of the recording.

Intracellular and extracellular solutions were used as in Henderson et al. (2016). The intracellular solution was as follows: $135 \mathrm{mM}$ K-gluconate, $5 \mathrm{mM} \mathrm{KCl,} 5 \mathrm{mM}$ EGTA, $0.5 \mathrm{mM} \mathrm{CaCl}_{2}, 10 \mathrm{mM}$ HEPES, $2 \mathrm{mM}$ Mg-ATP, and $0.1 \mathrm{mM}$ GTP. The $\mathrm{pH}$ of the intracellular solution was adjusted to 7.2 with Tris-base, and osmolarity was adjusted to $298 \mathrm{mOsmol}$ with sucrose. Just prior to gigaseal formation, the junction potential between the patch pipette and bath solutions was nulled. Chronic menthol and/or nicotine treatments were 24-30 hours long and began 24 hours after transfection. All recordings were performed 47-58 hours following the start of transfection (average of 51.75-52.75 hours across all treatments) (Tables 1-3).

Acetylcholine was dissolved in extracellular solution containing the following: $140 \mathrm{mM} \mathrm{NaCl}, 5 \mathrm{mM} \mathrm{KCl}, 2 \mathrm{mM} \mathrm{CaCl}_{2}, 1 \mathrm{mM} \mathrm{MgCl}_{2}, 10 \mathrm{mM}$ HEPES, and $10 \mathrm{mM}$ glucose (280-320 mOsmol, pH set to 7.3 with Trisbase). The $1 \mathrm{mM} \mathrm{Zn}^{2+}$ solutions were made from zinc acetate stock solutions, as in a previous study that tested $\mathrm{Zn}^{2+}$ sensitivity of rat $\alpha 3 \beta 4$ nAChRs (Hsiao et al., 2001).

For both [ACh]-response and $\mathrm{Zn}^{2+}$-inhibition experiments, $\mathrm{ACh}$ and/or $1 \mathrm{mM} \mathrm{Zn}^{2+}$ were applied by local laminar flow using an Octaflow II perfusion system [0.5-5 seconds; 6 psi; the Octaflow micromanifold tip (200 $\mu \mathrm{m}$ internal diameter) was located $\sim 1.0 \mathrm{~mm}$ from the Neuro-2a cell] (ALA Scientific Instruments, Farmingdale, 


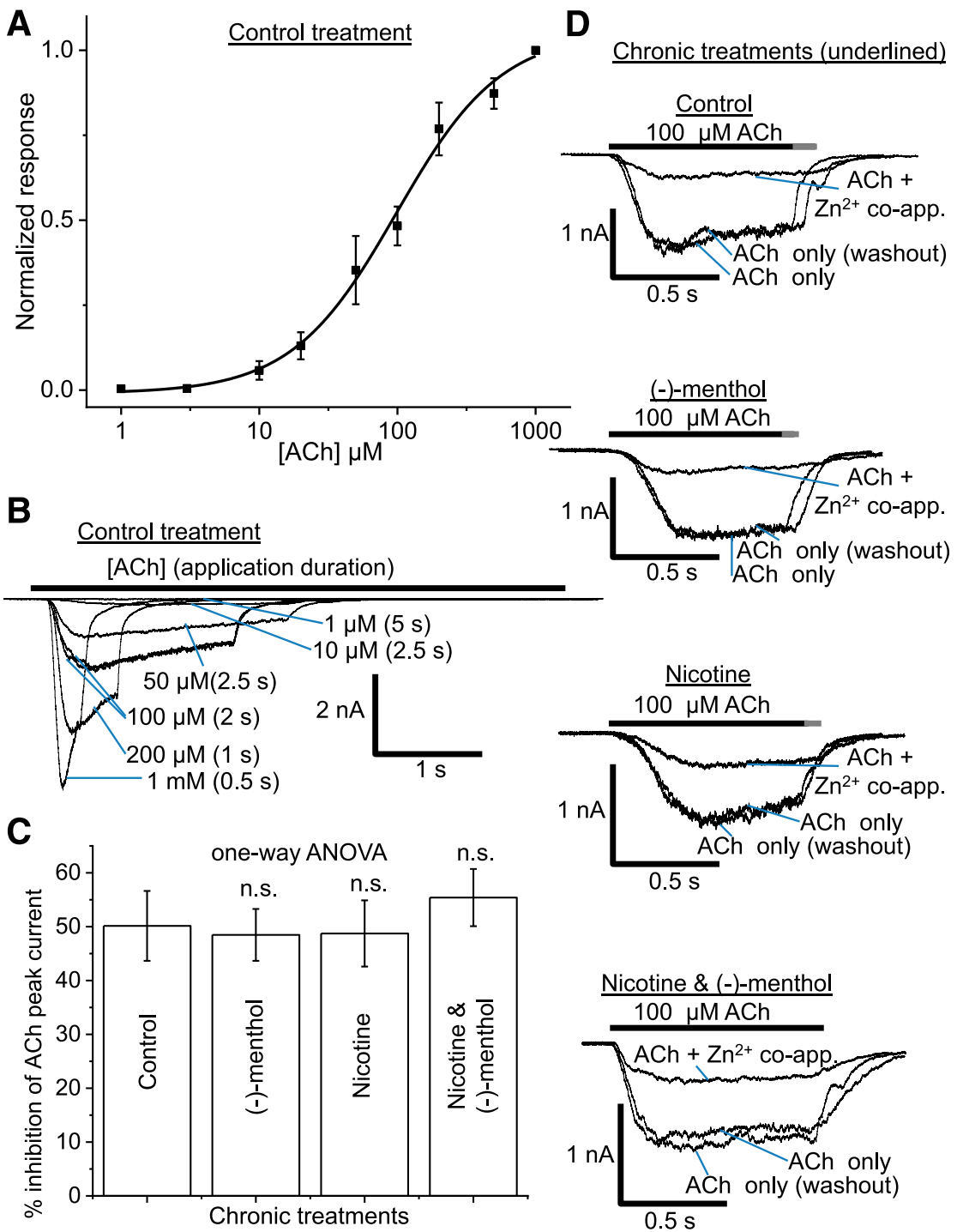

Fig. 1. Functional characterization shows that chronic (24-30 hours) (-)-menthol and/or nicotine treatment does not change the $\mathrm{Zn}^{2+}$ sensitivity of ACh-evoked currents at mouse $\alpha 3 \beta 4$ nAChRs. cDNAencoding mouse $\alpha 3$-GFP and WT $\beta 4$ subunits were transfected at a 1:1 ratio into Neuro-2a cells. Using whole-cell patch clamp at a holding potential $(-65 \mathrm{mV})$, inward current responses were recorded during ACh application at the indicated concentrations and the chronic treatment conditions were underlined. Menthol and/or nicotine were not present during ACh application. (A) [ACh]-response curves (average normalized response $\pm \mathrm{S}$.E. values are represented in the curve) were constructed ( $n=6-13$ for different concentrations). (B) Exemplar voltage-clamp current traces displayed by their ACh concentration and duration of application. (C) Chronic $500 \mathrm{nM}(-)$-menthol $(n=16)$, chronic $250 \mu \mathrm{M}$ nicotine $(n=19)$, and combined chronic $500 \mathrm{nM}(-)$-menthol and $250 \mu \mathrm{M}$ nicotine $(n=20)$ treatments did not significantly (n.s.) change the level of inhibition of $100 \mu \mathrm{M}$ ACh by $1 \mathrm{mM} \mathrm{Zn}^{2+}$ compared with control $(n=14)$ treatment $(P>0.05$ for both oneway ANOVA with post-hoc Tukey HSD test and twotailed $t$ tests). Mean \pm S.E. values are represented in the bar chart. The $1 \mathrm{mM} \mathrm{Zn}^{2+}$ solution without $\mathrm{ACh}$ was applied to the Neuro-2a cells for 2 seconds before it was coapplied with $100 \mu \mathrm{M}$ ACh for 1 second. (D) Exemplar traces of $100 \mu \mathrm{M}$ ACh only application 2.5 minutes before, during coapplication, and $100 \mu \mathrm{M}$ ACh only application 2.5 minutes after (washout) $100 \mu \mathrm{M} \mathrm{ACh}+1 \mathrm{mM} \mathrm{Zn^{2+ }}$ coapplication. The black bar represents ACh application for all three traces, and the adjoining gray bar represents the remaining $\mathrm{ACh}$ application for one to two traces (differences in application due to the variations in flow rates from the Octaflow manifold that combined solutions).

NY) onto voltage-clamped Neuro-2a cells (holding potential of $-65 \mathrm{mV}$, after correcting for a junction potential of $-16 \mathrm{mV}$ ). Actual current growth and decay times exceeded our calculated solution exchange time of $\sim 18$ milliseconds, probably because of deviations from laminar flow. Extracellular solution was perfused over the entire recording chamber at $\sim 2.7$ chamber volumes/min, while extracellular solution was also continuously perfused by local laminar flow at 2 psi (for 30 seconds to 5 minutes) from the Octaflow II perfusion system when $\mathrm{ACh}$ and/or $\mathrm{Zn}^{2+}$ were not being perfused. In the experiments, the nicotine- or menthol-containing medium was replaced by several washes with extracellular solution free of both nicotine and menthol, over an average period of 1.7 and 1.8 hours, respectively (minimum of 30 minutes). In experiments on Neuro-2a and other cultured mammalian cells, within 2 seconds after nicotine is removed from the extracellular solution, the intracellular solution [nicotine] falls to undetectable levels (Shivange et al., 2019); this rules out retention of nicotine intracellularly (Jia et al., 2003). We estimate that extracellular [nicotine] or [menthol] solution decreased to $<1 \mathrm{fM}$. Recordings were then commenced.

For [ACh]-response experiments, to avoid receptor desensitization from repetitive ACh application, we applied ACh at up to 5-minute intervals. There was no statistically significant current rundown in $n \geq 4$ Neuro-2a cells transfected with mouse $\alpha 3$-GFP $\beta 4$ nAChRs with three ACh applications at (duration of ACh application): $10 \mu \mathrm{M}$
(5 seconds) at 2-minute intervals; $50 \mu \mathrm{M}$ (5 seconds) at 3-minute intervals; $100 \mu \mathrm{M}$ ( 2 seconds) at 3-minute intervals; $500 \mu \mathrm{M}$ (1 second) at 5-minute intervals; and $1000 \mu \mathrm{M}(0.5$ seconds $)$ at 5-minute intervals $[P>0.05$, one-way ANOVA with post-hoc Tukey honestly significant difference (HSD) test]. Also, current rundown caused by $1 \mu \mathrm{M}$ ACh applied for the 5-second duration was ruled out by observing no significant difference between responses of $100 \mu \mathrm{M}$ ACh applied 3 minutes before and 30 seconds after this $1 \mu \mathrm{M}$ ACh application ( $P>0.05$, two-tailed $t$ test). Therefore, when collecting [ACh]-response data, ACh was applied at concentrations, durations, and time intervals that do not cause significant current rundown (i.e., $200 \mu \mathrm{M}$ ACh was applied for 1 second and allowed to recover for 5 minutes before the next ACh application, because $500 \mu \mathrm{M}$ ACh applied for 1 second at 5-minute intervals did not cause current rundown as explained previously). Up to six out of the nine ACh concentrations (1, $3,10,20,50,100,200,500$, and $1000 \mu \mathrm{M} \mathrm{ACh}$ ) were applied to the cell in each recording session, and $100 \mu \mathrm{M}$ ACh was applied twice in each recording session as a measure of current rundown. Peak current amplitudes were normalized to 1 for the maximum response for each recording session. The ACh concentrations were applied in a different order when recording at different cells. Data from different recording sessions were combined to form mean [ACh]-response curves for different chronic treatments. [ACh]-response data were fitted in Origin 2018 software (OriginLab Corporation, Northampton, MA) by 


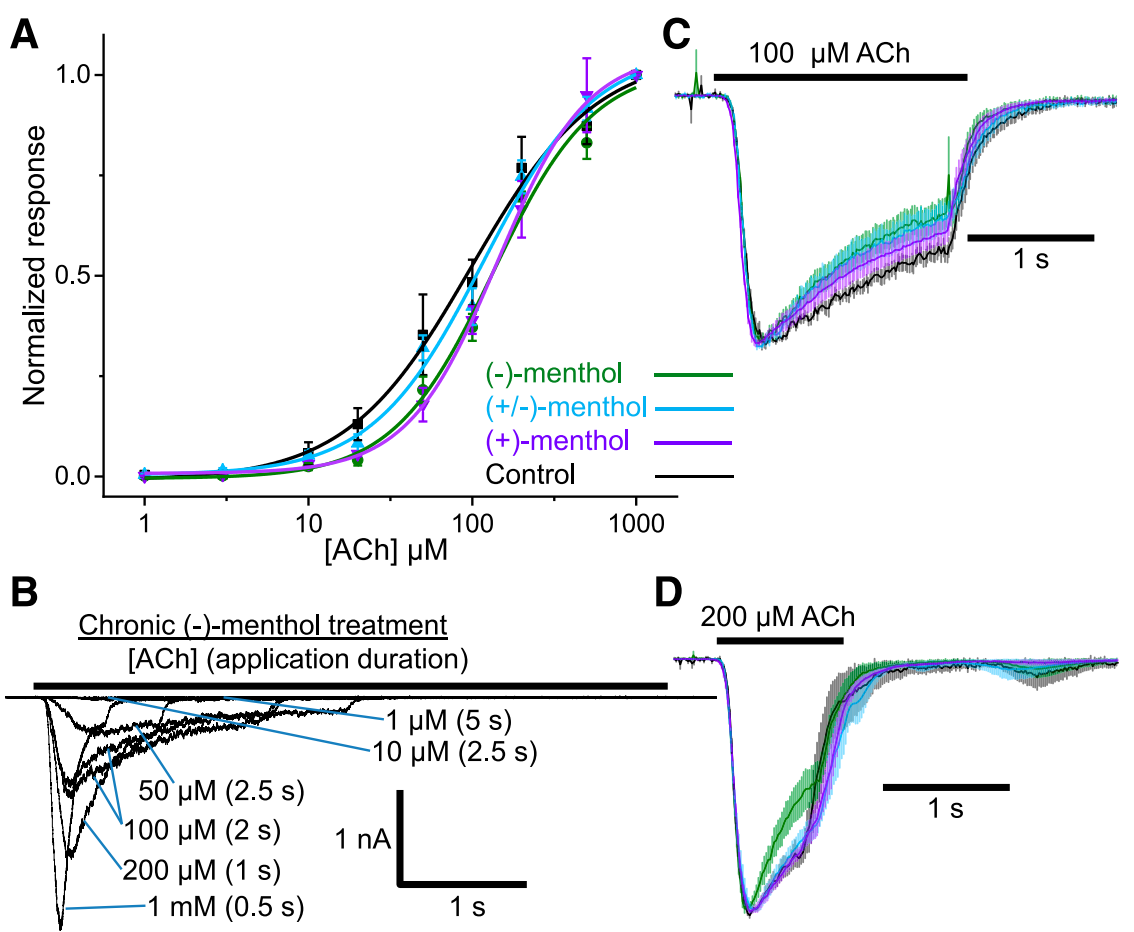

Fig. 2. Chronic (24-30 hours) menthol treatment does not shift the [ACh]-response relationship at mouse $\alpha 3 \beta 4 \mathrm{nAChRs}$ transfected into Neuro-2a cells, but accelerates desensitization kinetics. Menthol and/or nicotine were not present during ACh application. Chronic treatments key: control = black; $(-)$-menthol = green; $( \pm)$-menthol = blue; and (+)-menthol = purple. $(\mathrm{A})[\mathrm{ACh}]$-response curves (average normalized response \pm S.E. values are represented in the curves) were constructed for chronic treatments with $500 \mathrm{nM}(-)$-menthol, $500 \mathrm{nM}(+)$-menthol, and $500 \mathrm{nM}( \pm)$-menthol $(n=$ 5-12, 6-13, and 4-11, respectively, for the different concentrations) and plotted with control (no menthol, $n=6-13$, as in Fig. 1). $\mathrm{EC}_{50}$ values are given in Table 2. (B) Exemplar traces from chronic $500 \mathrm{nM}$ (-)-menthol treatment displayed by their ACh concentration and duration of application. (C and D). Chronic menthol treatment alters desensitization of $100 \mu \mathrm{M}(\mathrm{C})$ and $200 \mu \mathrm{M}$ (D) ACh-evoked currents. The percentage of current decay from the ACh-evoked peak was calculated at 1700 and $650 \mathrm{~ms}$ from the start of the ACh-evoked growth phase for the 100 and $200 \mu \mathrm{M}$ ACh applications, respectively. Mean current waveform curves with S.E. for no drug treated, and (-)-menthol, (+)-menthol, and ( \pm )-menthol treated chronically at transfected Neuro-2a cells [average of $12,12,11$, and 13 cells for $100 \mu \mathrm{M} \mathrm{ACh}(\mathrm{C})$, and average of $6,6,5$, and 6 cells for $200 \mu \mathrm{M}$ ACh (D), respectively]. Mean \pm S.E. values are represented in the waveforms in (C and D).

$$
y=A 1+(A 2-A 1) /\left(1+10^{[(\log x 0-x) \cdot p]}\right)
$$

where $y=$ response; $A 1=$ minimum response (usually near 0 ); $A 2=$ maximum response (near 1 ); $p=$ Hill coefficient; and $x=$ [ACh].

To compare desensitization between control and $500 \mathrm{nM}$ chronic (-)-menthol treatments, we calculated the percentage of current decay from the ACh-evoked peak at 1700 and 650 milliseconds from the start of the ACh-evoked growth phase for 100 and $200 \mu \mathrm{M} \mathrm{ACh}$ applications, respectively.

For $\mathrm{Zn}^{2+}$-inhibition experiments, $100 \mu \mathrm{M} \mathrm{ACh}$ (with or without $1 \mathrm{mM} \mathrm{Zn}^{2+}$ ) was applied for 1 second at 2.5-minute intervals, and $1 \mathrm{mM} \mathrm{Zn}^{2+}$ and $100 \mu \mathrm{M}$ ACh were coapplied in between the $100 \mu \mathrm{M}$ ACh only applications. Immediately prior to coapplication of $1 \mathrm{mM}$ $\mathrm{Zn}^{2+}$ and $100 \mu \mathrm{M} \mathrm{ACh}, 1 \mathrm{mM} \mathrm{Zn}^{2+}$ (without ACh) was applied to the cell for 2 seconds by local laminar flow at 6 psi from the Octaflow II perfusion system. For each $\mathrm{Zn}^{2+}$-inhibition experiment, there were four $100 \mu \mathrm{M}$ ACh only applications and three $1 \mathrm{mM} \mathrm{Zn}^{2+}$ and $100 \mu \mathrm{M}$ ACh coapplications. The percentage of $\mathrm{Zn}^{2+}$ inhibition for each experiment was calculated by

$$
100-\left[\left(\frac{x}{y}\right) \cdot 100\right]
$$

where $x=$ mean $100 \mu \mathrm{M}$ ACh peak current amplitude in the presence of $1 \mathrm{mM} \mathrm{Zn}^{2+}$, and $y=$ mean $100 \mu \mathrm{M}$ ACh peak current amplitude in the absence of $1 \mathrm{mM} \mathrm{Zn}^{2+}$.

For both [ACh]-response and $\mathrm{Zn}^{2+}$-inhibition experiments, data were discarded for individual recordings showing substantial current rundown (a >2-fold difference in current amplitude evoked by $100 \mu \mathrm{M}$ ACh applications). Neither menthol nor nicotine were present during any ACh applications in this study. Before the cell was recorded, the chronic nicotine and menthol treatments ended at average times of 1.7 and 1.8 hours, respectively.

Data Analyses. Clampfit 10.3 (Molecular Devices Axon Instruments) was used to analyze peak current amplitudes. In our figures, we moved electrophysiological traces along the time axis to account for variations in flow rates from the Octaflow manifold. Because peak inward current amplitudes of transfected $\alpha 3 \beta 4 \mathrm{nAChRs}$ in our data set and published data often exceed $-4 \mathrm{nA}$ (Krashia et al., 2010), recorded peak current amplitudes were further corrected for underestimation due to uncompensated $\mathrm{R}_{\mathrm{s}}(5 \%-15 \%)$ by assuming a linear current-voltage relationship and a reversal potential of $0 \mathrm{mV}$. Uncompensated $R_{\mathrm{S}}$ was multiplied by current amplitude to calculate the shift in membrane potential $\left(\mathrm{V}_{\mathrm{m}}\right)$. The shift in $\mathrm{V}_{\mathrm{m}}$ allowed us to estimate the size of underestimated current amplitudes [(shift in $\mathrm{V}_{\mathrm{m}}$ / holding $\mathrm{V}_{\mathrm{m}}$ of $-65 \mathrm{mV}$ ) $\times$ current amplitude]. Bar graphs, [ACh]response curve fitting, and average $100 \mu \mathrm{M}$ ACh and $200 \mu \mathrm{M}$ ACh

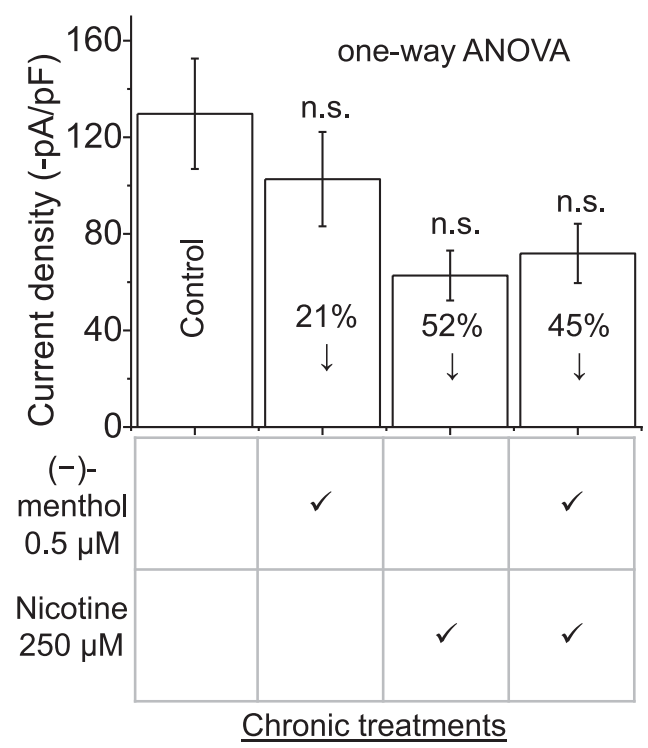

Fig. 3. Chronic (24-30 hours) (-)-menthol treatment does not alter functional PM levels of mouse $\alpha 3 \beta 4 \mathrm{nAChRs}$ transiently transfected into Neuro-2a cells. Summary of current density $(-\mathrm{pA} / \mathrm{pF})$ for the different chronic treatments [control, $500 \mathrm{nM}(-)$-menthol, $250 \mu \mathrm{M}$ nicotine, and combined $500 \mathrm{nM}(-)$-menthol and $250 \mu \mathrm{M}$ nicotine; $n=27,28,19$, and 20 , respectively]. n.s., not significantly changed $(P>0.05)$ by one-way ANOVA with post-hoc Tukey HSD test. Mean \pm S.E. values are represented in the bar chart. Menthol and/or nicotine were not present during ACh application. 
TABLE 1

Level (\%) of $1 \mathrm{mM} \mathrm{Zn}{ }^{2+}$ inhibition of $100 \mu \mathrm{M}$ ACh currents at mouse $\alpha 3 \beta 4 \mathrm{nAChRs}$ under different chronic $(24-30 \mathrm{~h})$ treatments

Cells were studied 52.5-52.75 $\mathrm{h}$ after the start of transfection and 26.5-27.25 $\mathrm{h}$ after the start of incubation in no drugcontaining media or after addition of menthol and/or nicotine (both durations are averages). Mean \pm S.E. values are represented in the table.

\begin{tabular}{|c|c|c|c|c|}
\hline Chronic Treatment & Control & (-)-Menthol & Nicotine & $\begin{array}{l}\text { Nicotine and } \\
(-) \text {-Menthol }\end{array}$ \\
\hline (-)-Menthol (nM) & 0 & 500 & 0 & 500 \\
\hline Nicotine $(\mu \mathrm{M})$ & 0 & 0 & 250 & 250 \\
\hline$\% \mathrm{Zn}^{2+}$ inhibition ${ }^{a}(\%)$ & $50.1 \pm 6.5$ & $48.5 \pm 4.8$ & $48.7 \pm 6.1$ & $55.4 \pm 5.3$ \\
\hline$N$ & 14 & 16 & 19 & 20 \\
\hline Cell capacitance $(\mathrm{pF})^{a}$ & $28.2 \pm 5.3$ & $23.3 \pm 2.5$ & $22.5 \pm 1.9$ & $22.9 \pm 1.9$ \\
\hline Current density $(\mathrm{pA} / \mathrm{pF})^{a, b}$ & $-108.4 \pm 31.6$ & $-91.4 \pm 15.6$ & $-62.7 \pm 10.4$ & $-71.9 \pm 12.3$ \\
\hline
\end{tabular}

${ }^{a} P>0.05$ for one-way ANOVA with post-hoc Tukey HSD test.

${ }^{b}$ Current density between these same chronic treatments with higher $N$ numbers for control and chronic (-)-menthol treatment are shown in Table 3 and discussed in Results in the section entitled Chronic Nicotine But Not Chronic Menthol Treatment Reduces Functional PM Mouse $\alpha 3 \beta 4$ nAChR Levels.

waveforms were completed and plotted in Origin 2018 (OriginLab Corportion). We performed statistical tests (one-way ANOVA with post-hoc Tukey HSD test and two-tailed $t$ tests) using Origin 2018 software (OriginLab Corportion) and/or Microsoft Excel (Redmond, WA). Mean \pm S.E. values are represented in bar charts, average waveforms, and tables (Figs. 1-3; Tables 1-3).

\section{Results}

Chronic Menthol Treatment Does Not Alter the Stoichiometry of Functional Mouse $\alpha 3 \beta 4$ nAChRs. To help understand how menthol in mentholated cigarettes may influence nicotine dependence, we studied how the functional characteristics of mouse $\alpha 3 \beta 4 \mathrm{nAChRs}$ are altered by chronic (24-30 hours) $500 \mathrm{nM}$ menthol treatment. In Neuro$2 \mathrm{a}$ cells transiently transfected with mouse $\alpha 3$-GFP and $\beta 4$ nAChR subunits at a 1:1 ratio, we studied whole-cell patchclamp currents. This Neuro-2a cell system has proven amenable for studies of chronic nicotine and/or chronic menthol treatment effects on $\alpha 4 \beta 2$ and $\alpha 6 \beta 2 \mathrm{nAChRs}$ (Srinivasan et al., 2011, 2012b; Henderson et al., 2014, 2017; Henderson and Lester, 2015). Some clonal cell types express transfected membrane proteins at levels so high that aspects of subunit assembly, membrane tracking, and turnover become limiting, distorting regulatory processes that occur in neurons (Dávila-García et al., 1999; Xiao and Kellar, 2004; Lomazzo et al., 2011). Neuro-2a cells have more modest expression levels than various HEK293derived cell lines, allowing good control of membrane proteins (Moss et al., 2009). In previous studies of Neuro2 a cells transfected with $\alpha 4 \beta 2$ and $\alpha 6 \beta 2 \mathrm{nAChRs}$, varying the ratio of transfected subunits does affect the stoichiometry of the nAChRs (Srinivasan et al., 2012a; Fox et al., 2015) - and exposure to chronic nicotine does upregulate nAChRs (Srinivasan et al., 2011, 2012a,b; Fox et al., 2015) and exposure to menthol alone also upregulates nAChRs (Henderson et al., 2016).

From our experiments, the $\mathrm{EC}_{50}$ for $\mathrm{ACh}$ is $99 \mu \mathrm{M}(n=6-13)$ (Fig. 1, A and B). Our $\mathrm{EC}_{50}$ is similar to the $\mathrm{EC}_{50}$ of $92 \mu \mathrm{M}$ for $\mathrm{ACh}$ at Xenopus oocytes injected with mouse $\alpha 3$-GFP and $\beta 4$ nAChR-encoding complementary RNAs (obtained from the same cDNA constructs used for our experiments) at a 2:3 ratio, respectively (Shih et al., 2014). Furthermore, our $\mathrm{EC}_{50}$ value for ACh at mouse $\alpha 3$-GFP and $\beta 4 \mathrm{nAChRs}$ transfected in Neuro-2a cells is consistent with $\mathrm{EC}_{50}$ values for ACh at WT and modified mouse, rat, and human $\alpha 3$ and $\beta 4 \mathrm{nAChRs}$ encoding complementary RNAs injected into oocytes, as well as for human WT $\alpha 3$ and $\beta 4$ nAChRs encoding complementary DNAs transfected at a 1:1 ratio in HEK293 cells (Wang et al., 1998; Drenan et al., 2008; Grishin et al., 2010; Krashia et al., 2010).

$\mathrm{Zn}^{2+}$-Inhibition of ACh-Evoked Currents at Mouse $\alpha 3-G F P \beta 4$ nAChRs Following Chronic Menthol and/or Nicotine Treatment. Because our ACh-induced currents in transfected mouse $\alpha 3 \beta 4 \mathrm{nAChRs}$ and transfected human nAChRs $\alpha 3 \beta 4 \mathrm{~s}$ have similar $\mathrm{EC}_{50}$ values and waveforms as previously published data (Krashia et al., 2010), we hypothesized that we would find similar effects of $\mathrm{Zn}^{2+}$ on $100 \mu \mathrm{M}$ $\mathrm{ACh}$ at mouse and human nAChRs $\alpha 3 \beta 4 \mathrm{~s}$. We employed $\mathrm{Zn}^{2+}$ to assess stoichiometry. Moreover, synaptic vesicles of forebrain neurons contain $\mathrm{Zn}^{2+}$ (Frederickson et al., 2000). $\mathrm{Zn}^{2+}$ is released from neurons calcium and depolarization dependently, reaching estimated transient concentrations of almost $300 \mu \mathrm{M}$ (Assaf and Chung, 1984; Howell et al., 1984).

Krashia et al. (2010) assessed the effects of $\mathrm{Zn}^{2+}$ on AChevoked currents at human $\alpha 3 \beta 4 \mathrm{nAChRs}$ of different stoichiometries. Krashia et al. (2010) showed that a wide range of $\left[\mathrm{Zn}^{2+}\right]$ differentially affected the two $\alpha 3 \beta 4 \mathrm{nAChR}$ stoichiometries. Within this range, $1 \mathrm{mM} \mathrm{Zn}^{2+}$ actually produced opposite effects on ACh-evoked currents at the two populations, enhancing $(\alpha 3)_{2}(\beta 4)_{3}$ but inhibiting $(\alpha 3)_{3}(\beta 4)_{2}$ (Krashia et al., 2010). Therefore, we chose $1 \mathrm{mM} \mathrm{Zn}^{2+}$ as a sensitive way to determine mouse $\alpha 3 \beta 4 \mathrm{nAChR}$ stoichiometry changes by chronic drug treatments. If chronic menthol treatment (with or without co-chronic nicotine treatment) shifts toward the $(\alpha 3)_{3}(\beta 4)_{2}$ stoichiometry, we expect greater levels of inhibition by $1 \mathrm{mM} \mathrm{Zn}{ }^{2+}$ compared with no chronic menthol treatment (with or without co-chronic nicotine treatment, respectively). Using western blotting with coimmunoprecipitation of total cell lysates, Mazzo et al. (2013) found that $1 \mathrm{mM}$ nicotine treatment of 24 hours causes a shift $(62 \%)$ toward $(\alpha 3)_{2}(\beta 4)_{3}$ from the $(\alpha 3)_{3}(\beta 4)_{2}$ stoichiometry in transfected HeLa cells. We used a lower concentration of $250 \mu \mathrm{M}$ nicotine in our experiments to avoid potential nonspecific effects caused by alkaline $\mathrm{pH}$ shifts with $1 \mathrm{mM}$ nicotine. Nicotine concentrations of similar range (hundreds of micromolars) exist transiently in the airway surface liquid of smokers (Clunes et al., 2008; Mazzo et al., 2013), and $\alpha 3 \beta 4 \mathrm{nAChRs}$ may enhance the growth of lung cancers (Improgo et al., 2010, 2013). Therefore, the nicotine concentration we study in our experiments has pharmacological relevance. Neither of the chronic treatments 
TABLE 2

[ACh] response at mouse $\alpha 3 \beta 4 \mathrm{nAChRs}$ under different chronic (24-30 h) treatments

Cells were studied 51.75-52.75 h after the start of transfection and 25.75-26.5 h after the start of incubation in no drug-containing media or after menthol was added (both durations are averages). Mean \pm S.E. values are represented in the table.

\begin{tabular}{|c|c|c|c|c|}
\hline Chronic Treatment & Control & (-)-Menthol & $( \pm)$-Menthol & (+)-Menthol \\
\hline$N$ & $6-13$ & $5-12$ & $4-11$ & $6-13$ \\
\hline $\mathrm{EC}_{50}(\mu \mathrm{M})$ & $99 \pm 14$ & $134 \pm 18$ & $117 \pm 16$ & $142 \pm 5$ \\
\hline Hill slope & $1.14 \pm 0.18$ & $1.42 \pm 0.24$ & $1.28 \pm 0.21$ & $1.59 \pm 0.07$ \\
\hline Cell capacitance $(\mathrm{pF})^{a}$ & $19.7 \pm 1.9$ & $20.0 \pm 3.7$ & $17.6 \pm 2.0$ & $16.0 \pm 1.9$ \\
\hline Current density $(\mathrm{pA} / \mathrm{pF})$ of $100 \mu \mathrm{M}$ ACh currents ${ }^{a}$ & $-153.2 \pm 33.3$ & $-117.1 \pm 41.4$ & $-196.9 \pm 42.9$ & $-214.5 \pm 33.4$ \\
\hline Current density $(\mathrm{pA} / \mathrm{pF})$ of $1 \mathrm{mM}$ ACh currents ${ }^{a}$ & $-363.1 \pm 84.6$ & $-295.9 \pm 86.7$ & $-440.5 \pm 64.1$ & $-566.1 \pm 84.4$ \\
\hline
\end{tabular}

significantly changed the cell capacitance relative to control treatment $(P>0.05$ for one-way ANOVA with post-hoc Tukey HSD test) (Table 1).

In the absence of nicotine, chronic $500 \mathrm{nM}(-)$-menthol treatment of 24-30 hours did not significantly alter the percentage of $1 \mathrm{mM} \mathrm{Zn}^{2+}$-inhibition of $100 \mu \mathrm{M}$ ACh-evoked currents compared with control treatment (no menthol and no nicotine) $(P>0.05$ for one-way ANOVA with post-hoc Tukey HSD test, $48.5 \% \pm 4.8 \%$ vs. $50.1 \% \pm 6.5 \%, n=16$ and 14 , respectively) (Fig. 1, C and D; Table 1). In addition, neither chronic $250 \mu \mathrm{M}$ nicotine alone $(48.7 \% \pm 6.1 \%, n=19)$, nor combined chronic $250 \mu \mathrm{M}$ nicotine and $500 \mathrm{nM}(-)$-menthol $(55.4 \% \pm 5.3 \%, n=20)$ treatments significantly altered the level of $1 \mathrm{mM} \mathrm{Zn}^{2+}$-inhibition of $100 \mu \mathrm{M}$ ACh-evoked current compared with control treatment $(P>0.05$ for both treatments for one-way ANOVA with post-hoc Tukey HSD test) (Fig. 1, C and D; Table 1). This result indicates that compared with control treatment, neither of the chronic treatments [(-)-menthol alone, nicotine alone, or (-)-menthol and nicotine combined] changes the stoichiometry of mouse $\alpha 3 \beta 4$ $\mathrm{nAChRs}$. Also, combined chronic $250 \mu \mathrm{M}$ nicotine and $500 \mathrm{nM}$ (-)-menthol treatment did not significantly alter the level of $1 \mathrm{mM} \mathrm{Zn^{2+ }}$ inhibition of $100 \mu \mathrm{M}$ ACh-evoked current compared with chronic $250 \mu \mathrm{M}$ nicotine treatment alone $(55.4 \% \pm$ $5.3 \%$ vs. $48.7 \% \pm 6.1 \% ; P>0.05$ for one-way ANOVA with post-hoc Tukey HSD test; $n=20$ and 19, respectively) (Fig. 1, $\mathrm{C}$ and $\mathrm{D}$; Table 1). This result emphasizes that chronic $500 \mathrm{nM}$ (-)-menthol does not influence $1 \mathrm{mM} \mathrm{Zn}^{2+}$ sensitivity of AChevoked currents at mouse $\alpha 3 \beta 4 \mathrm{nAChRs}$. Because these control, chronically menthol-treated, and/or chronically nicotine-treated $\alpha 3 \beta 4 \mathrm{nAChRs}$ all showed $>45 \%$ inhibition by $1 \mathrm{mM} \mathrm{Zn}^{2+}$ (Fig. 1, C and D; Table 1), we suggest that most mouse $\alpha 3 \beta 4 \mathrm{nAChRs}$ in these transfected Neuro-2a cells possess the $(\alpha 3)_{3}(\beta 4)_{2}$ stoichiometry. If these $\alpha 3 \beta 4 \mathrm{nAChRs}$ under the different chronic treatments were predominantly in the $(\alpha 3)_{2}(\beta 4)_{3}$ stoichiometry, ACh-evoked currents would show potentiation in the presence of $1 \mathrm{mM} \mathrm{Zn}^{2+}$ (Krashia et al., 2010). Our suggestion is also consistent with the Krashia et al. (2010) study, which strongly suggested that HEK293 cells transfected with $\alpha 3$ and $\beta 4 \mathrm{nAChR}$ subunits at a 1:1 ratio predominantly possess the $(\alpha 3)_{3}(\beta 4)_{2}$ stoichiometry. Krashia et al. (2010) suggested this predominant $(\alpha 3)_{3}(\beta 4)_{2}$ stoichiometry after observing greater shifts in the $\mathrm{EC}_{50}$ of $\mathrm{ACh}$ in patch-clamp recorded transfected cells containing mutant $\alpha 3$ and WT $\beta 4$ compared with cells containing WT $\alpha 3$ and mutant $\beta 4 \mathrm{nAChR}$ constructs.

[ACh]-Response at Mouse $\alpha 3-$ GFP $\beta 4$ nAChRs Following Chronic Menthol Treatment. As another experiment to probe stoichiometry changes by chronic menthol, we assessed the [ACh]-response relationship at mouse $\alpha 3$-GFP $\beta 4$ $\mathrm{nAChRs}$ following chronic menthol treatment. Previous studies have shown how populations of different stoichiometries vary in the $\mathrm{ACh} \mathrm{EC}_{50}$ values by 2 - to 3 -fold at human $\alpha 3 \beta 4$ nAChRs (Krashia et al., 2010) and 7- to 8-fold at rat $\alpha 3 \beta 4$ nAChRs (Grishin et al., 2010). Because Krashia et al. (2010) found that $\mathrm{Zn}^{2+}$ inhibition is sensitive to $\alpha 3 \beta 4 \mathrm{nAChR}$ stoichiometry, our previous $\mathrm{Zn}^{2+}$-inhibition experiments do present strong evidence that chronic exposure to (-)-menthol and/or nicotine fails to affect $\alpha 3 \beta 4 \mathrm{nAChR}$ stoichiometry. However, we recently reported that (-)-menthol and $(+)$-menthol have markedly different effects in chronic exposure at $\alpha 4 \beta 2 \mathrm{nAChRs}$ (http://www.eneuro.org/content/ eneuro/early/2018/12/20/ENEURO.0465-18.2018.full.pdf). Furthermore, cigarette manufacturers could consider responding to possible governmental bans on cigarettes containing (-)-menthol (https:/www.fda.gov/NewsEvents/ Newsroom/PressAnnouncements/ucm625884.htm), which is now the predominant isoform in mentholated cigarettes, by adding (+)-menthol instead. Therefore, we extended the experiments to determine whether chronic exposures to other forms of menthol [( \pm$)$-menthol or $(+)$-menthol] alter $\alpha 3 \beta 4 \mathrm{nAChR}$ stoichiometry. Neither of the chronic menthol treatments significantly changed the cell capacitance relative to control treatment ( $P>0.05$ for one-way ANOVA with post-hoc Tukey HSD test) (Table 2).

Chronic treatments with either $500 \mathrm{nM}(-)$-menthol $\left(\mathrm{EC}_{50}=\right.$ $134 \mu \mathrm{M} ; n=5-12), 500 \mathrm{nM}( \pm)$-menthol $\left(\mathrm{EC}_{50}=117 \mu \mathrm{M} ; n=\right.$ $4-11)$, or $500 \mathrm{nM}(+)-m e n t h o l\left(\mathrm{EC}_{50}=142 \mu \mathrm{M} ; n=6-13\right)$ for 24-30 hours did not shift the $\mathrm{EC}_{50}$ value of $\mathrm{ACh}$ by $>1.5$-fold compared with control treatment (no menthol and no nicotine; $\mathrm{EC}_{50}=99 \mu \mathrm{M} ; n=6-13$ ) at Neuro-2a cells transfected with mouse $\alpha 3$-GFP and WT $\beta 4 \mathrm{nAChR}$ subunits (Fig. 2, A and B; Table 2). These [ACh]-response experiments together with the $\mathrm{Zn}^{2+}$-inhibition experiments suggest that chronic menthol treatment does not shift the stoichiometry of functional mouse $\alpha 3 \beta 4$ nAChRs. The [ACh] response of control and chronic menthol-treated cells have Hill slope values between 1 and 2 (Table 2 ), as similarly reported in the published literature for $\alpha 3 \beta 4 \mathrm{nAChRs}$ (Grishin et al., 2010; Krashia et al., 2010; Shih et al., 2014). Furthermore, compared with control treatment, the different chronic menthol treatments did not significantly change the current density $(\mathrm{pA} / \mathrm{pF})$ of $100 \mu \mathrm{M}$ ACh-evoked currents or $1 \mathrm{mM}$ ACh-evoked currents $(P>0.05$ for one-way ANOVA with post-hoc Tukey HSD test in both cases) (Table 2).

The operational definition of desensitization is a decline in agonist-induced conductance while the agonist is present. Ton et al. (2015) have previously shown that acute menthol application accelerates desensitization of currents at the $\alpha 3 \beta 4$ 
TABLE 3

Current density $(\mathrm{pA} / \mathrm{pF})$ at mouse $\alpha 3 \beta 4 \mathrm{nAChRs}$ under different chronic $(24-30 \mathrm{~h})$ treatments

Cells were studied 52.5-52.75 h after the start of transfection and $26.5-27.0 \mathrm{~h}$ after the start of incubation in no drugcontaining media or after addition of menthol and/or nicotine (both durations are averages). Mean \pm S.E. values are represented in the table.

\begin{tabular}{lcccc}
\hline \multicolumn{1}{c}{ Chronic Treatment } & Control & $(-)$-Menthol & Nicotine & $\begin{array}{c}\text { Nicotine and } \\
(-) \text {-Menthol }\end{array}$ \\
\hline (-)-Menthol $(\mathrm{nM})$ & 0 & 500 & 0 & 500 \\
Nicotine $(\mu \mathrm{M})$ & 0 & 0 & 250 & 250 \\
Cell capacitance $(\mathrm{pF})^{a}$ & $24.1 \pm 3.0$ & $21.9 \pm 2.1$ & $22.5 \pm 1.9$ & $22.9 \pm 1.9$ \\
Current density $(\mathrm{pF} / \mathrm{pA})^{a}$ & $-129.7 \pm 22.9$ & $-102.7 \pm 19.6$ & $-62.7 \pm 10.4$ & $-71.9 \pm 12.3$ \\
$N$ & 27 & 28 & 19 & 20 \\
\hline
\end{tabular}

${ }^{a} P>0.05$ for one-way ANOVA with post-hoc Tukey HSD test.

nAChR by accessing the open state of the channel, and our experiments with chronic menthol treatment in the absence of acutely applied menthol and prior to agonist activation may highlight another mechanism for modulating desensitization. We assessed effects of chronic menthol exposure on desensitization. Compared with control treatment, chronic treatment with $500 \mathrm{nM}(-)$-menthol significantly accelerated desensitization of $100 \mu \mathrm{M}$ ACh-evoked currents at mouse $\alpha 3$-GFP $\beta 4$ nAChRs $[P<0.05$ for the two-tailed $t$ test, $39.8 \% \pm 3.5 \%(n=$ $12)$ vs. $52.7 \% \pm 5.1 \%(n=12)$ current decay for control and chronic (-)-menthol treatment, respectively, at 1700 milliseconds from the start of the ACh-evoked growth phase] (Fig. 2C). Also, compared with control treatment, chronic treatment with $500 \mathrm{nM}(-)$-menthol significantly accelerated desensitization of $200 \mu \mathrm{M}$ ACh-evoked currents at mouse $\alpha 3$-GFP $\beta 4$ nAChRs $[P<0.01$ for the two-tailed $t$ test, $21.6 \% \pm 3.4 \%$ $(n=6)$ vs. $45.1 \% \pm 5.7 \%(n=6)$ current decay for control and chronic (-)-menthol treatment, respectively, at 650 milliseconds from the start of the ACh-evoked growth phase] (Fig. 2D). Our results follow the known pattern that, at higher agonist concentrations, nAChR currents desensitize more rapidly. We also tested whether, for a given ACh concentration, higher agonist-induced currents desensitize more rapidly. We pooled data for $100 \mu \mathrm{M}$ ACh-evoked currents, and separately, for $200 \mu \mathrm{M}$ ACh-evoked currents, for the four chronic treatments [control, (-)-menthol, ( \pm )-menthol, and (+)-menthol], with a criterion of $>100 \mathrm{pA} / \mathrm{pF}$ to eliminate noisy contribution from relatively small signals. We compared the peak current density $(\mathrm{pA} / \mathrm{pF})$ and percentage of desensitization at 1700 and 650 milliseconds after the start of the growth phase [for $100 \mu \mathrm{M}(n=29)$ and $200 \mu \mathrm{M}$ ACh-evoked currents $(n=20)$, respectively]. For both the 100 and $200 \mu \mathrm{M}$ ACh-evoked current data sets, we found no significant Pearson's correlation coefficient between peak current density and desensitization (ANOVA).

Chronic Nicotine But Not Chronic Menthol Treatment Reduces Functional PM Mouse $\alpha 3 \beta 4$ nAChR Levels. We analyzed our data set to assess functional PM levels of mouse $\alpha 3 \beta 4 \mathrm{nAChRs}$ following chronic treatments with $500 \mathrm{nM}(-)$-menthol, $250 \mu \mathrm{M}$ nicotine alone, combined $250 \mu \mathrm{M}$ nicotine and $500 \mathrm{nM}(-)$-menthol, and control (neither menthol nor nicotine). The current density (peak current amplitude in $\mathrm{pA} /$ cell capacitance in $\mathrm{pF}$ ) is an appropriate metric for functional PM levels of the mouse $\alpha 3 \beta 4 \mathrm{nAChR}$. Unlike quantitative reverse-transcription polymerase chain reaction or western blot, whole-cell patch-clamp electrophysiology can reveal alterations in functional nAChR PM levels or alterations from post-translational changes. Neither of the chronic treatments in this current density analysis significantly changed the cell capacitance relative to control treatment $(P>0.05$ for one-way ANOVA with post-hoc Tukey HSD test) (Table 3). In this section, we report on the results of $t$ tests as we consider the subtle differences discussed subsequently as important findings in the field of regulation of nAChRs.

Chronic (-)-menthol treatment alone has no statistically significant effect on the current density of mouse $\alpha 3 \beta 4$ nAChRs compared with control treatment (no chronic nicotine or menthol $)(P>0.05$ for both one-way ANOVA with post-hoc Tukey HSD test and two-tailed $t$ test; $-102.7 \pm 19.6 \mathrm{pA} / \mathrm{pF}$ vs. $-129.7 \pm 22.9 \mathrm{pA} / \mathrm{pF}, n=28$ and 27 , respectively) (Fig. 3 ; Table 3). Furthermore, combined chronic (-)-menthol and nicotine treatment had no statistically significant effect on the current density of mouse $\alpha 3 \beta 4$ nAChRs compared with chronic nicotine treatment alone $(P>0.05$ for both one way-ANOVA with post-hoc Tukey HSD test and twotailed $t$ test; $-71.9 \pm 12.3 \mathrm{pA} / \mathrm{pF}$ vs. $-62.7 \pm 10.4 \mathrm{pA} / \mathrm{pF}$, $n=20$ and 19 , respectively) (Fig. 3; Table 3). Interestingly, compared with control treatment (no chronic nicotine or menthol), both chronic $250 \mu \mathrm{M}$ nicotine treatment alone $(P<0.05$ by two tailed $t$ test, $P>0.05$ by one-way ANOVA with post-hoc Tukey HSD test; $-129.7 \pm 22.9 \mathrm{pA} / \mathrm{pF}$ vs. $-62.7 \pm 10.4 \mathrm{pF} / \mathrm{pA}, n=27$ and 19 , respectively; $52 \%$ decrease) and combined chronic $250 \mu \mathrm{M}$ nicotine and $500 \mathrm{nM}$ menthol treatment $(P<0.05$ by two tailed $t$ test, $P>0.05$ by one way-ANOVA with post-hoc Tukey HSD test; $-129.7 \pm$ $22.9 \mathrm{pA} / \mathrm{pF}$ vs. $-71.9 \pm 12.3 \mathrm{pA} / \mathrm{pF}, n=27$ and 20 , respectively; $45 \%$ decrease) caused a reduction in the current density of mouse $\alpha 3 \beta 4$ nAChRs (Fig. 3; Table 3). Therefore, chronic nicotine treatment at $250 \mu \mathrm{M}$ causes a reduction in functional mouse $\alpha 3 \beta 4$ nAChR PM levels in Neuro-2a cells. Because we extensively washed the nicotine $(250 \mu \mathrm{M})$ for $\geq 30$ minutes, and usually 100 minutes, in nicotine-free extracellular solution before the recording session (see Materials and Methods), for that cell no classically defined desensitization process would adequately describe the reduced function.

\section{Discussion}

We undertook these experiments to understand whether chronic exposure to submicromolar menthol alters the properties of $\alpha 3 \beta 4 \mathrm{nAChRs}$, whose abundance in the medial habenula-interpeduncular pathway may dominate the aversive properties of nicotine. The pharmacokinetics of menthol in humans have proven challenging to study, presumably because menthol is glucuronidated via first-pass metabolism 
(Gelal et al., 1999), but we have estimated elsewhere that menthol concentrations in the brain of a mouse model of smoking are 0.5-2.5 $\mu \mathrm{M}$ (Henderson et al., 2016, 2017).

Long-term pharmacological effects on PM levels of nAChRs proceed, at least in part, via differential trafficking of the major subunit stoichiometries, $\alpha_{2} \beta_{3}$ versus $\alpha_{3} \beta_{2}$. Therefore, we sought to measure both subunit stoichiometry and PM nAChR levels. Chronic (24-30 hours) menthol treatment at $500 \mathrm{nM}$ neither significantly altered subunit stoichiometry $\left[(\alpha 3)_{2}(\beta 4)_{3}\right.$ vs. $\left.(\alpha 3)_{3}(\beta 4)_{2}\right]$ on the PM nor significantly changed functionally measured PM protein levels of mouse nAChR $\alpha 3 \beta 4$ ( $P>0.05$ for both).

Faced with this insensitivity to chronic menthol, we sought to know whether chronic nicotine itself affects either functional PM stoichiometry or functional PM protein levels in mouse $\alpha 3 \beta 4 \mathrm{nAChR}$ levels in the Neuro-2a cell assay system. Surprisingly, chronic nicotine at a concentration many times that found in the blood following smoking decreased rather than increased the current density of $100 \mu \mathrm{M}$ ACh-evoked currents, indicating reduced functional mouse $\alpha 3 \beta 4$ PM protein levels.

The $\beta$ subunit is probably the dominant factor causing the contrast between chronic nicotine and/or menthol effects on $\alpha 4 \beta 2$ and $\alpha 6 \beta 2$, versus on $\alpha 3 \beta 4$. In our assay system, $\alpha 4 \beta 4$ $\mathrm{nAChRs}$ are exported efficiently from the ER to the PM; most $\alpha 4 \beta 2$ nAChRs are not (Richards et al., 2011; Srinivasan et al., 2011). That is, in the absence of nicotine, mouse $\alpha 4 \beta 4 \mathrm{nAChRs}$ are already highly distributed in the PM relative to the ER. Previous experiments have shown a mechanistic basis for this difference. The mouse nAChR $\beta 4$ subunit has an ER export motif (LXM), but no ER retention motif (RRQR), and these properties explain how mouse $\alpha 3 \beta 4 \mathrm{nAChRs}$ efficiently exit the ER to reach the PM (Srinivasan et al., 2011; Mazzo et al., 2013). Indeed, the crucial interaction may occur at the single previously nonbinding $\beta$ subunit, also termed accessory (Crespi et al., 2018b). Mouse $\alpha 4$-eGFP $\beta 2 \mathrm{nAChRs}$ with modified $\beta 2$ subunits containing an export motif and without the ER retention motif were strongly localized to the PM relative to the ER (2.36-fold increase in PM-integrated density over mouse $\alpha 4$-eGFP WT $\beta 2 \mathrm{nAChRs}$ ), and the chronic (48 hours) nicotine treatment at $100 \mathrm{nM}$ caused only a modest (1.2-fold) additional increase in the PM integrated density (Srinivasan et al., 2011). However, the chronic (48 hours) nicotine treatment at $100 \mathrm{nM}$ upregulated mouse $\alpha 4$-GFP WT $\beta 2 \mathrm{nAChRs}$ more substantially (1.9-fold increase in PM-integrated density) (Srinivasan et al., 2011). The export motif is absent in both the nAChR $\alpha 3$ subunit and mouse $\mathrm{nAChR} \beta 2$ subunit, while the mouse $\mathrm{nAChR} \beta 4$ subunit contains an ER export motif (Srinivasan et al., 2011; Mazzo et al., 2013). Therefore, it is mechanistically understandable how mouse $\mathrm{nAChR} \alpha 3 \beta 4 \mathrm{nAChRs}$ have a high PM versus ER distribution without additional aids to ER export of $\alpha 3 \beta 4$ nAChRs.

What is the relevance to chronic effects of menthol? Previous experiments show that chronic submicromolar menthol also apparently acts in the early exocytotic pathway to aid the ER exit of nAChRs (Henderson et al., 2016, 2017). The observed details of chronic menthol effects differ from those of chronic nicotine effects, and probably also from the acute blocking effects of menthol at [menthol] $>100$-fold higher than our chronically applied concentrations (Ton et al., 2015). We tentatively suggested that chronic submicromolar menthol could act as a nonspecific chemical chaperone for $\alpha 4 \beta 2$ and $\alpha 6 \beta 2$ nAChRs (Henderson et al., 2016); however, the target could also be another protein in the early exocytotic pathway. In any case, because $\alpha 3 \beta 4 \mathrm{nAChRs}$ do not experience a ratelimiting step in the early exocytotic pathway due to the absence of an ER retention motif, it is mechanistically understandable that menthol treatment causes no further increase in the already high existing PM versus ER distribution.

Certain more subtle effects of chronic submicromolar menthol cannot be ruled out. Chronic $500 \mathrm{nM}$ (-)-menthol treatment accelerated desensitization of ACh-evoked currents at mouse $\alpha 3 \beta 4 \mathrm{nAChRs}$, even $>1$ hour after we washed out the menthol. This effect is unlikely to arise from a menthol$\mathrm{nAChR}$ binding with a lifetime of $\sim 1$ hour. We can also rule out sequelae of (-)-menthol interactions with TRPM8, the classic menthol target, because Neuro-2a cells do not express TRPM8 mRNA (Henderson et al., 2016). However, phosphorylation of nAChRs does, in some cases, enhance desensitization (Huganir et al., 1986; Hopfield et al., 1988; Nishizaki and Sumikawa, 1998; Di Angelantonio et al., 2011). Whether an unknown pathway activates protein kinase(s) during chronic exposure to $500 \mathrm{nM}$ (-)-menthol, and whether nAChR phosphorylation is stable for $>1$ hour after the menthol is removed, cannot be evaluated at the present time.

The steps leading to functional $\alpha 3 \beta 4 \mathrm{nAChRs}$ reaching the cell membrane include: 1) assembly of subunits into a pentamer; and 2) post-assembly trafficking, which can be affected by degradation of the pentamer. While our experiments and previously published data indicate that $\alpha 3$ and $\beta 4$ subunits preferentially assemble into a $(\alpha 3)_{3}(\beta 4)_{2}$ stoiochiometry (Krashia et al., 2010), this stoichiometry is still prone to degradation (Mazzo et al., 2013). Therefore, our patch-clamp experiments mainly record currents from the $(\alpha 3)_{3}(\beta 4)_{2}$ stoichiometry because the $(\alpha 3)_{2}(\beta 4)_{3}$ stoichiometry may reach the plasma membrane less efficiently due to possibly lower pentamer assembly. Additional intracellular $(\alpha 3)_{3}(\beta 4)_{2}$ complexes formed in the presence of chronic menthol may undergo degradation before they can be trafficked to the PM. Preliminary data from our laboratory lend support for such a mechanism, but at higher menthol concentrations than used here (Patowary et al., 2016).

Mechanism of Downregulation by Chronic Nicotine. Previous experiments indicate that chronic treatments with nicotine have less dramatic effects on protein levels of $\mathrm{nAChR}$ $\alpha 3 \beta 4$ compared with $\mathrm{nAChR} \alpha 4 \beta 2$ in several brain regions studied (Wang et al., 1998; Meyer et al., 2001; DávilaGarcía et al., 2003; Nguyen et al., 2003; Fox et al., 2015; Marks et al., 2015). In a contrasting report, chronic (14 days) nicotine treatment in rats caused downregulation of $\mathrm{nAChR}$ $\alpha 3 \beta 4$-like binding sites in the subiculum and cerebellum (Nguyen et al., 2003). Although efficient membrane trafficking usually limits further increases in the PM levels of $\alpha 3 \beta 4 \mathrm{nAChRs}$, Mazzo et al. (2013) skillfully rendered membrane tracking the rate-limiting step by inhibiting protein synthesis with cycloheximide. Under these circumstances, nicotine-induced upregulation of human $\alpha 3 \beta 4$ nAChRs occurs through the increased stability of the $(\alpha 3)_{2}(\beta 4)_{3}$ stoichiometry (Mazzo et al., 2013), leading to increased trafficking to the PM. It is unlikely that chronic nicotine treatment would cause decreased current density of $100 \mu \mathrm{M}$ ACh-evoked currents through a shift toward the lower potency mouse $(\alpha 3)_{3}(\beta 4)_{2} \mathrm{nAChR}$ stoichiometry 
because: 1) when Neuro-2a cells in our study or HEK293 cells in another study were transfected with $\alpha 3$ and $\beta 4$ $\mathrm{nAChRs}$ at a 1:1 ratio, the level of $\mathrm{Zn}^{2+}$-inhibition of $\mathrm{ACh}$ evoked currents suggests $(\alpha 3)_{3}(\beta 4)_{2}$ as the predominant stoichiometry (Krashia et al., 2010); and 2) if nicotine shifts $\alpha 3 \beta 4$ nAChR stoichiometry, it would be toward $(\alpha 3)_{2}(\beta 4)_{3}$ (Mazzo et al., 2013), since nicotine shifting toward a stoichiometry of three $\alpha$ and two $\beta$ subunits of any nAChR has not been previously reported.

Our finding that nicotine-induced downregulation of mouse $\alpha 3 \beta 4 \mathrm{nAChRs}$ is not common, but recalls experiments on other nAChRs. In toxin binding studies in rodents or primates, nicotine downregulates $\alpha 6^{*} \mathrm{nAChRs}$ in some cases (Lai et al., 2005; McCallum et al., 2006b; Mugnaini et al., 2006) but not others (McCallum et al., 2006a; Visanji et al., 2006), and the effect depends on the detailed stoichiometry of the complex (Perez et al., 2008; Fox et al., 2015).

Further Questions and Conclusions. It will be interesting to study whether chronic menthol treatment has different effects at $\alpha 3 \beta 4$ versus $\alpha 3 \beta 4 \alpha 5 \mathrm{nAChRs}$, analogous to the differential modulation by lynx1 of human $\alpha 3 \beta 4$ and $\alpha 3 \beta 4 \alpha 5$ nAChRs (George et al., 2017). Furthermore, functional $\alpha 3 \beta 4 \beta 3 \mathrm{nAChRs}$ are present in the brain (Grady et al., 2009). It remains possible that the subunit in the accessory position influences the nature of the subunit interfaces (Walsh et al., 2018), and hence potentially the effects from chronic treatments by menthol or other chaperones.

In conclusion, chronic menthol treatment (500 nM, 2430 hours) failed to shift the [ACh]-response relationship and $\mathrm{Zn}^{2+}$ sensitivity of ACh-evoked currents at mouse $\alpha 3 \beta 4$ nAChRs, suggesting no change in receptor stoichiometry at the PM. Furthermore, compared with no drug treatment, the current density of 100 ACh-evoked currents was not significantly changed following chronic menthol treatment $(P>0.05)$, indicating that functional mouse $\alpha 3 \beta 4 \mathrm{nAChR} \mathrm{PM}$ levels were not changed. Mechanistically, these data are broadly consistent with the view that chronic effects of submicromolar menthol act via events in the early exocytotic pathway. Pathopharmacologically, our data sets suggest that smoking mentholated cigarettes, which enhances smoking addiction and nicotine addiction, exerts these effects via mechanisms other than chronic submicromolar exposure of $\alpha 3 \beta 4$ nAChRs.

\section{Acknowledgments}

We are grateful to Suparna Patowary for performing preliminary experiments on chronic menthol treatment effects at mouse $\alpha 3 \beta 4$ nAChRs (Patowary et al., 2016).

\section{Authorship Contributions}

Participated in research design: Bavan, Henderson, Lester.

Conducted experiments: Bavan, Kim.

Performed data analysis: Bavan, Henderson, Lester.

Wrote or contributed to the writing of the manuscript: Bavan, Kim, Henderson, Lester.

\section{References}

Assaf SY and Chung SH (1984) Release of endogenous $\mathrm{Zn}^{2+}$ from brain tissue during activity. Nature 308:734-736.

Bierut LJ, Stitzel JA, Wang JC, Hinrichs AL, Grucza RA, Xuei X, Saccone NL, Saccone SF, Bertelsen S, Fox L, et al. (2008) Variants in nicotinic receptors and risk for nicotine dependence. Am J Psychiatry 165:1163-1171.

Brody AL, Mukhin AG, La Charite J, Ta K, Farahi J, Sugar CA, Mamoun MS, Vellios E, Archie M, Kozman M, et al. (2013) Up-regulation of nicotinic acetylcholine receptors in menthol cigarette smokers. Int $J$ Neuropsychopharmacol 16:957-966.
Buisson B and Bertrand D (2001) Chronic exposure to nicotine upregulates the human $\alpha 4 \beta 2$ nicotinic acetylcholine receptor function. $J$ Neurosci 21:1819-1829.

Chen X, Chen J, Williamson VS, An SS, Hettema JM, Aggen SH, Neale MC, and Kendler KS (2009) Variants in nicotinic acetylcholine receptors $\alpha 5$ and $\alpha 3$ increase risks to nicotine dependence. Am J Med Genet B Neuropsychiatr Genet 150B:926-933.

Clunes LA, Bridges A, Alexis N, and Tarran R (2008) In vivo versus in vitro airway surface liquid nicotine levels following cigarette smoke exposure. J Anal Toxicol 32: 201-207.

Crespi A, Colombo SF, and Gotti C (2018a) Proteins and chemical chaperones involved in neuronal nicotinic receptor expression and function: an update. $B r J$ Pharmacol 175:1869-1879.

Crespi A, Plutino S, Sciaccaluga M, Righi M, Borgese N, Fucile S, Gotti C, and Colombo SF (2018b) The fifth subunit in $\alpha 3 \beta 4$ nicotinic receptor is more than an accessory subunit. FASEB $J$ 32:4190-4202.

Dávila-García MI, Houghtling RA, Qasba SS, and Kellar KJ (1999) Nicotinic receptor binding sites in rat primary neuronal cells in culture: characterization and their regulation by chronic nicotine. Brain Res Mol Brain Res 66:14-23.

Dávila-García MI, Musachio JL, and Kellar KJ (2003) Chronic nicotine administration does not increase nicotinic receptors labeled by $\left[{ }^{125} \mathrm{I}\right]$ epibatidine in adrenal gland, superior cervical ganglia, pineal or retina. J Neurochem 85:1237-1246.

Di Angelantonio S, Piccioni A, Moriconi C, Trettel F, Cristalli G, Grassi F, and Limatola C (2011) Adenosine A2A receptor induces protein kinase A-dependent functional modulation of human $\alpha 3 \beta 4$ nicotinic receptor. J Physiol 589:2755-2766.

Dineley-Miller K and Patrick J (1992) Gene transcripts for the nicotinic acetylcholine receptor subunit, $\beta 4$, are distributed in multiple areas of the rat central nervous system. Brain Res Mol Brain Res 16:339-344.

Drenan RM, Nashmi R, Imoukhuede P, Just H, McKinney S, and Lester HA (2008) Subcellular trafficking, pentameric assembly, and subunit stoichiometry of neuronal nicotinic acetylcholine receptors containing fluorescently labeled $\alpha 6$ and $\beta 3$ subunits. Mol Pharmacol 73:27-41.

Flores CM, Rogers SW, Pabreza LA, Wolfe BB, and Kellar KJ (1992) A subtype of nicotinic cholinergic receptor in rat brain is composed of alpha 4 and beta 2 subunits and is up-regulated by chronic nicotine treatment. Mol Pharmacol 41:31-37.

Fowler CD, Lu Q Johnson PM, Marks MJ, and Kenny PJ (2011) Habenular $\alpha 5$ nicotinic receptor subunit signalling controls nicotine intake. Nature 471:597-601.

Fox AM, Moonschi FH, and Richards CI (2015) The nicotine metabolite, cotinine, alters the assembly and trafficking of a subset of nicotinic acetylcholine receptors. $J$ Biol Chem 290:24403-24412.

Frahm S, Slimak MA, Ferrarese L, Santos-Torres J, Antolin-Fontes B, Auer S, Filkin $\mathrm{S}$, Pons S, Fontaine JF, Tsetlin V, et al. (2011) Aversion to nicotine is regulated by the balanced activity of $\beta 4$ and $\alpha 5$ nicotinic receptor subunits in the medial habenula. Neuron 70:522-535.

Frederickson CJ, Suh SW, Silva D, Frederickson CJ, and Thompson RB (2000) Importance of zinc in the central nervous system: the zinc-containing neuron. J Nutr 130(Suppl 5S):1471S-1483S

Gandhi KK, Foulds J, Steinberg MB, Lu SE, and Williams JM (2009) Lower quit rates among African American and Latino menthol cigarette smokers at a tobacco treatment clinic. Int $J$ Clin Pract 63:360-367.

Gelal A, Jacob P III, Yu L, and Benowitz NL (1999) Disposition kinetics and effects of menthol. Clin Pharmacol Ther 66:128-135.

George AA, Bloy A, Miwa JM, Lindstrom JM, Lukas RJ, and Whiteaker P (2017) Isoform-specific mechanisms of $\alpha 3 \beta 4^{*}$-nicotinic acetylcholine receptor modulation by the prototoxin lynx1. FASEB $J$ 31:1398-1420.

Grady SR, Moretti M, Zoli M, Marks MJ, Zanardi A, Pucci L, Clementi F, and Gotti C (2009) Rodent habenulo-interpeduncular pathway expresses a large variety of uncommon nAChR subtypes, but only the $\alpha 3 \beta 4 *$ and $\alpha 3 \beta 3 \beta 4 *$ subtypes mediate acetylcholine release. $J$ Neurosci 29:2272-2282.

Grishin AA, Wang CI, Muttenthaler M, Alewood PF, Lewis RJ, and Adams DJ (2010) $\alpha$-Conotoxin AuIB isomers exhibit distinct inhibitory mechanisms and differential sensitivity to stoichiometry of $\alpha 3 \beta 4$ nicotinic acetylcholine receptors. $J$ Biol Chem 285:22254-22263.

Hans M, Wilhelm M, and Swandulla D (2012) Menthol suppresses nicotinic acetylcholine receptor functioning in sensory neurons via allosteric modulation. Chem Senses 37:463-469.

Henderson BJ and Lester HA (2015) Inside-out neuropharmacology of nicotinic drugs. Neuropharmacology 96:178-193.

Henderson BJ, Srinivasan R, Nichols WA, Dilworth CN, Gutierrez DF, Mackey ED, McKinney S, Drenan RM, Richards CI, and Lester HA (2014) Nicotine exploits a COPI-mediated process for chaperone-mediated up-regulation of its receptors. $J$ Gen Physiol 143:51-66.

Henderson BJ, Wall TR, Henley BM, Kim CH, McKinney S, and Lester HA (2017) Menthol enhances nicotine reward-related behavior by potentiating nicotineinduced changes in $\mathrm{nAChR}$ function, nAChR upregulation, and DA neuron excitability. Neuropsychopharmacology 42:2285-2291.

Henderson BJ, Wall TR, Henley BM, Kim CH, Nichols WA, Moaddel R, Xiao C, and Lester HA (2016) Menthol alone upregulates midbrain nAChRs, alters nAChR subtype stoichiometry, alters dopamine neuron firing frequency, and prevents nicotine reward. $J$ Neurosci 36:2957-2974.

Hopfield JF, Tank DW, Greengard P, and Huganir RL (1988) Functional modulation of the nicotinic acetylcholine receptor by tyrosine phosphorylation. Nature 336:677-680

Howell GA, Welch MG, and Frederickson CJ (1984) Stimulation-induced uptake and release of zinc in hippocampal slices. Nature 308:736-738.

Hsiao B, Dweck D, and Luetje CW (2001) Subunit-dependent modulation of neuronal nicotinic receptors by zinc. J Neurosci 21:1848-1856.

Huganir RL, Delcour AH, Greengard P, and Hess GP (1986) Phosphorylation of the nicotinic acetylcholine receptor regulates its rate of desensitization. Nature 321:774-776.

Improgo MR, Schlichting NA, Cortes RY, Zhao-Shea R, Tapper AR, and Gardner PD (2010) ASCL1 regulates the expression of the CHRNA5/A3/B4 lung cancer susceptibility locus. Mol Cancer Res 8:194-203. 
Improgo MR, Soll LG, Tapper AR, and Gardner PD (2013) Nicotinic acetylcholine receptors mediate lung cancer growth. Front Physiol 4:251.

Jia L, Flotildes K, Li M, and Cohen BN (2003) Nicotine trapping causes the persistent desensitization of $\alpha 4 \beta 2$ nicotinic receptors expressed in oocytes. J Neurochem 84:753-766.

Krashia P, Moroni M, Broadbent S, Hofmann G, Kracun S, Beato M, Groot-Kormelink PJ, and Sivilotti LG (2010) Human $\alpha 3 \beta 4$ neuronal nicotinic receptors show different stoichiometry if they are expressed in Xenopus oocytes or mammalian HEK293 cells. PLoS One 5:e13611.

Lai A, Parameswaran N, Khwaja M, Whiteaker P, Lindstrom JM, Fan H, McIntosh JM, Grady SR, and Quik M (2005) Long-term nicotine treatment decreases striatal $\alpha 6^{*}$ nicotinic acetylcholine receptor sites and function in mice. Mol Pharmacol 67: $1639-1647$.

Lomazzo E, Hussmann GP, Wolfe BB, Yasuda RP, Perry DC, and Kellar KJ (2011) Effects of chronic nicotine on heteromeric neuronal nicotinic receptors in rat primary cultured neurons. $J$ Neurochem 119:153-164.

Marks MJ, O’Neill HC, Wynalda-Camozzi KM, Ortiz NC, Simmons EE, Short CA, Butt CM, McIntosh JM, and Grady SR (2015) Chronic treatment with varenicline changes expression of four nAChR binding sites in mice. Neuropharmacology 99 $142-155$

Marks MJ, Pauly JR, Gross SD, Deneris ES, Hermans-Borgmeyer I, Heinemann SF, and Collins AC (1992) Nicotine binding and nicotinic receptor subunit RNA after chronic nicotine treatment. J Neurosci 12:2765-2784.

Mazzo F, Pistillo F, Grazioso G, Clementi F, Borgese N, Gotti C, and Colombo SF (2013) Nicotine-modulated subunit stoichiometry affects stability and trafficking of $\alpha 3 \beta 4$ nicotinic receptor. $J$ Neurosci 33:12316-12328.

McCallum SE, Parameswaran N, Bordia T, Fan H, McIntosh JM, and Quik M (2006a) Differential regulation of mesolimbic $\alpha 3 / \alpha 6 \beta 2$ and $\alpha 4 \beta 2$ nicotinic acetylcholine receptor sites and function after long-term oral nicotine to monkeys. $J$ Pharmacol Exp Ther 318:381-388.

McCallum SE, Parameswaran N, Bordia T, Fan H, Tyndale RF, Langston JW, McIntosh JM, and Quik M (2006b) Increases in $\alpha 4^{*}$ but not $\alpha 3^{*} / \alpha 6^{*}$ nicotinic receptor sites and function in the primate striatum following chronic oral nicotine treatment. J Neurochem 96:1028-1041.

Meyer EL, Xiao Y, and Kellar KJ (2001) Agonist regulation of rat $\alpha 3 \beta 4$ nicotinic acetylcholine receptors stably expressed in human embryonic kidney 293 cells. Mol Pharmacol 60:568-576.

Moss FJ, Imoukhuede PI, Scott K, Hu J, Jankowsky JL, Quick MW, and Lester HA (2009) GABA transporter function, oligomerization state, and anchoring: correlates with subcellularly resolved FRET. J Gen Physiol 134:489-521.

Mugnaini M, Garzotti M, Sartori I, Pilla M, Repeto P, Heidbreder CA, and Tessari M (2006) Selective down-regulation of $\left[{ }^{125} \mathrm{I}_{\mathrm{Y}} \mathrm{Y}_{0^{-}} \alpha\right.$-conotoxin MII binding in rat mesostriatal dopamine pathway following continuous infusion of nicotine. Neuroscience 137:565-572.

Nashmi R and Lester H (2007) Cell autonomy, receptor autonomy, and thermodynamics in nicotine receptor up-regulation. Biochem Pharmacol 74:1145-1154.

Nguyen HN, Rasmussen BA, and Perry DC (2003) Subtype-selective up-regulation by chronic nicotine of high-affinity nicotinic receptors in rat brain demonstrated by receptor autoradiography. J Pharmacol Exp Ther 307:1090-1097.

Nishizaki T and Sumikawa K (1998) Effects of PKC and PKA phosphorylation on desensitization of nicotinic acetylcholine receptors. Brain Res 812:242-245.

Patowary S, Mackey EDW, McKinney SL, Deshpande P, Henderson BJ, Biener G, Raicu V, and Lester HA (2016) Effects of menthol on $\alpha 3 \beta 4^{*}$ nicotinic receptors. Biophys J 110:603.

Perez XA, Bordia T, McIntosh JM, Grady SR, and Quik M (2008) Chronic nicotine treatment differentially regulates striatal $\alpha 6 \alpha 4 \beta 2^{*}$ and $\alpha 6$ (non $\left.\alpha 4\right) \beta 2 * \mathrm{nAChR}$ expression and function. Mol Pharmacol 74:844-853.

Richards CI, Srinivasan R, Xiao C, Mackey ED, Miwa JM, and Lester HA (2011) Trafficking of $\alpha 4^{*}$ nicotinic receptors revealed by superecliptic phluorin: effects of a $\beta 4$ amyotrophic lateral sclerosis-associated mutation and chronic exposure to nicotine. J Biol Chem 286:31241-31249.

Saccone SF, Hinrich AL, Saccone NL, Chase GA, Konvicka K, Madden PA, Breslau N, Johnson EO, Hatsukami D, Pomerleau O, et al. (2007) Cholinergic nicotinic receptor genes implicated in a nicotine dependence association study targeting 348 candidate genes with 3713 SNPs. Hum Mol Genet 16:36-49.

Sheffield EB, Quick MW, and Lester RA (2000) Nicotinic acetylcholine receptor subunit mRNA expression and channel function in medial habenula neurons. Neuropharmacology 39:2591-2603.

Shih PY, Engle SE, Oh G, Deshpande P, Puskar NL, Lester HA, and Drenan RM (2014) Differential expression and function of nicotinic acetylcholine receptors in subdivisions of medial habenula. $J$ Neurosci 34:9789-9802.

Shivange A, Borden P, Muthusamy A, Nichols A, Bera K, Bao H, Bishara I, Jeon J, Mulcahy M, Cohen B, et al. (2019). Nicotinic drugs in the endoplasmic reticulum: beginning the inside-out pathway of addiction and therapy. J Gen Physiol, in press.

Spitz MR, Amos CI, Dong Q, Lin J, and Wu X (2008) The CHRNA5-A3 region on chromosome 15q24-25.1 is a risk factor both for nicotine dependence and for lung cancer. J Natl Cancer Inst 100:1552-1556.

Srinivasan R, Pantoja R, Moss FJ, Mackey EDW, Son CD, Miwa J, and Lester HA (2011) Nicotine up-regulates $\alpha 4 \beta 2$ nicotinic receptors and ER exit sites via stoichiometry-dependent chaperoning. J Gen Physiol 137:59-79.

Srinivasan R, Richards CI, Dilworth C, Moss FJ, Dougherty DA, and Lester HA (2012a) Förster resonance energy transfer (FRET) correlates of altered subunit stoichiometry in cys-loop receptors, exemplified by nicotinic $\alpha 4 \beta 2$. Int J Mol Sci 13 : 10022-10040.

Srinivasan R, Richards CI, Xiao C, Rhee D, Pantoja R, Dougherty DA, Miwa JM, and Lester HA (2012b) Pharmacological chaperoning of nicotinic acetylcholine receptors reduces the endoplasmic reticulum stress response. Mol Pharmacol 81: $759-769$.

Tobacco and Genetics Consortium (2010) Genome-wide meta-analyses identify multiple loci associated with smoking behavior. Nat Genet 42:441-447.

Ton HT, Smart AE, Aguilar BL, Olson TT, Kellar KJ, and Ahern GP (2015) Menthol enhances the desensitization of human $\alpha 3 \beta 4$ nicotinic acetylcholine receptors. $\mathrm{Mol}$ Pharmacol 88:256-264.

Visanji NP, Mitchell SN, O'Neill MJ, and Duty S (2006) Chronic pre-treatment with nicotine enhances nicotine-evoked striatal dopamine release and $\alpha 6$ and $\beta 3$ nicotinic acetylcholine receptor subunit mRNA in the substantia nigra pars compacta of the rat. Neuropharmacology 50:36-46.

Walsh RM Jr, Roh SH, Gharpure A, Morales-Perez CL, Teng J, and Hibbs RE (2018) Structural principles of distinct assemblies of the human $\alpha 4 \beta 2$ nicotinic receptor. Nature 557:261-265.

Wang F, Nelson ME, Kuryatov A, Olale F, Cooper J, Keyser K, and Lindstrom J (1998) Chronic nicotine treatment up-regulates human $\alpha 3 \beta 2$ but not $\alpha 3 \beta 4$ acetylcholine receptors stably transfected in human embryonic kidney cells. J Biol Chem 273:28721-28732.

Whiteaker P, McIntosh JM, Luo S, Collins AC, and Marks MJ (2000) ${ }^{125} \mathrm{I}$ - $\alpha$-conotoxin MII identifies a novel nicotinic acetylcholine receptor population in mouse brain. Mol Pharmacol 57:913-925.

Whiteaker P, Peterson CG, Xu W, McIntosh JM, Paylor R, Beaudet AL, Collins AC, and Marks MJ (2002) Involvement of the $\alpha 3$ subunit in central nicotinic binding populations. $J$ Neurosci 22:2522-2529.

Xiao C, Nashmi R, McKinney S, Cai H, McIntosh JM, and Lester HA (2009) Chronic nicotine selectively enhances $\alpha 4 \beta 2 *$ nicotinic acetylcholine receptors in the nigrostriatal dopamine pathway. $J$ Neurosci 29:12428-12439.

Xiao Y and Kellar KJ (2004) The comparative pharmacology and up-regulation of rat neuronal nicotinic receptor subtype binding sites stably expressed in transfected mammalian cells. J Pharmacol Exp Ther 310:98-107.

Address correspondence to: Selvan Bavan, Division of Biology and Biological Engineering, California Institute of Technology, 1200 East California Blvd., Pasadena, CA 91125. E-mail: sbavan@caltech.edu; or Henry A. Lester, Division of Biology and Biological Engineering, California Institute of Technology, 1200 East California Blvd., Pasadena, CA 91125. E-mail: lester@ caltech.edu 